\title{
Occupational Morbidities and their Association with Nutrition and Environmental Factors among Textile Workers of Desert Areas of Rajasthan, India
}

\author{
Madhu B. Singh, Ranjana Fotedar and J. Lakshminarayana \\ Desert Medicine Research Centre (ICMR), India
}

\begin{abstract}
Occupational Morbidities and their Association with Nutrition and Environmental Factors among Textile Workers of Desert Areas of Rajasthan, India: Madhu B. Singh, et al. Desert Medicine Research Centre (ICMR), India-In Rajasthan 21,000 workers are engaged in hand processing textile industries (process gray/raw cotton cloth). They are exposed to hazards of the textile industries besides the harsh conditions of the desert which contributes to adverse effects on their health. To explore the occupational health problems of the desert textile workers and their association with nutrition and environmental factors, investigations were carriedout in two districts, Jodhpur and Pali. Data on occupational disease conditions, environmental factors, nutritional deficiency signs and anemia were collected for a total of 1,240 individuals out of which 845 were textile workers and 395 were comparative group workers of the same age groups. The main disease conditions, i.e. aches (19.4\%), respiratory (12.1\%) and fever $(7.7 \%)$, were higher in textile workers than the comparative group. Dyeing group workers suffered the most (25.5\%) from aches, significantly higher than the comparative group (11.6\%), may be due to a higher percentage of severe anemia, besides physical labour. Printing and bleaching group workers suffered from respiratory problems (15.5\%) almost twice as much as the comparative group, possibly due to exposure to fumes of acids and use of chemical dyes. Housing conditions, personal hygiene and education showed negative associations with disease conditions but positive associations with anemia. The study revealed that in the textile industry, disease conditions vary with the categorization of work. The findings suggest the need for implementation of safety measures according to the type of work in textile industries, besides
\end{abstract}

Received Dec 28, 2004; Accepted May 18, 2005

Correspondence to: M. B. Singh, Desert Medicine Research Center (ICMR), New Pali Road, Jodhpur-342005, India

(e-mail:mbsgh@yahoo.com) extension of health and nutrition education and welfare programs.

(J Occup Health 2005; 47: 371-377)

Key words: Occupational morbidities, Textile workers, Smoking, Desert, Environment

In developing countries, high prevalence of manual and heavy physical work combined with lack of general health and social protection warrant an urgent need to develop occupational health services ${ }^{1)}$ giving due consideration to general health needs besides improvement of health and environment. The occupational health standards of workers and workplaces vary substantially according to the structure, level of industrialization, developmental status, climatic conditions and traditions of occupational health and safety. According to WHO 20 to 50 percent of workers are subjected to hazardous exposures in industrialized countries and the rate may be even higher in developing countries $^{1)}$.

In desert districts of Rajasthan, Pali, Jodhpur and Barmer, about 21,000 workers are engaged in various type of activities in hand processing textile industries. They process gray/raw cotton cloth through various stages such as caustisizing (continuous caustic padding: passing the gray/raw cotton cloth through caustic soda), bleaching, dyeing, printing and finishing (stentering: sizing of cloth for maintaining the width of cloth, felt finishing and packing). These workers are not only exposed to the harsh conditions of the desert but also to the hazards of the textile industries, both affecting their health adversely. The major health problems reported in the literature at international $^{2-5)}$ and national ${ }^{6,7)}$ levels are mainly respiratory and musculoskeletal pain, headache. Occupational health problems of workers of the desert areas of Rajasthan, exposed to hazards of the textile industry, have not yet been explored. The present study was conducted with the aim of exploring the occupational 


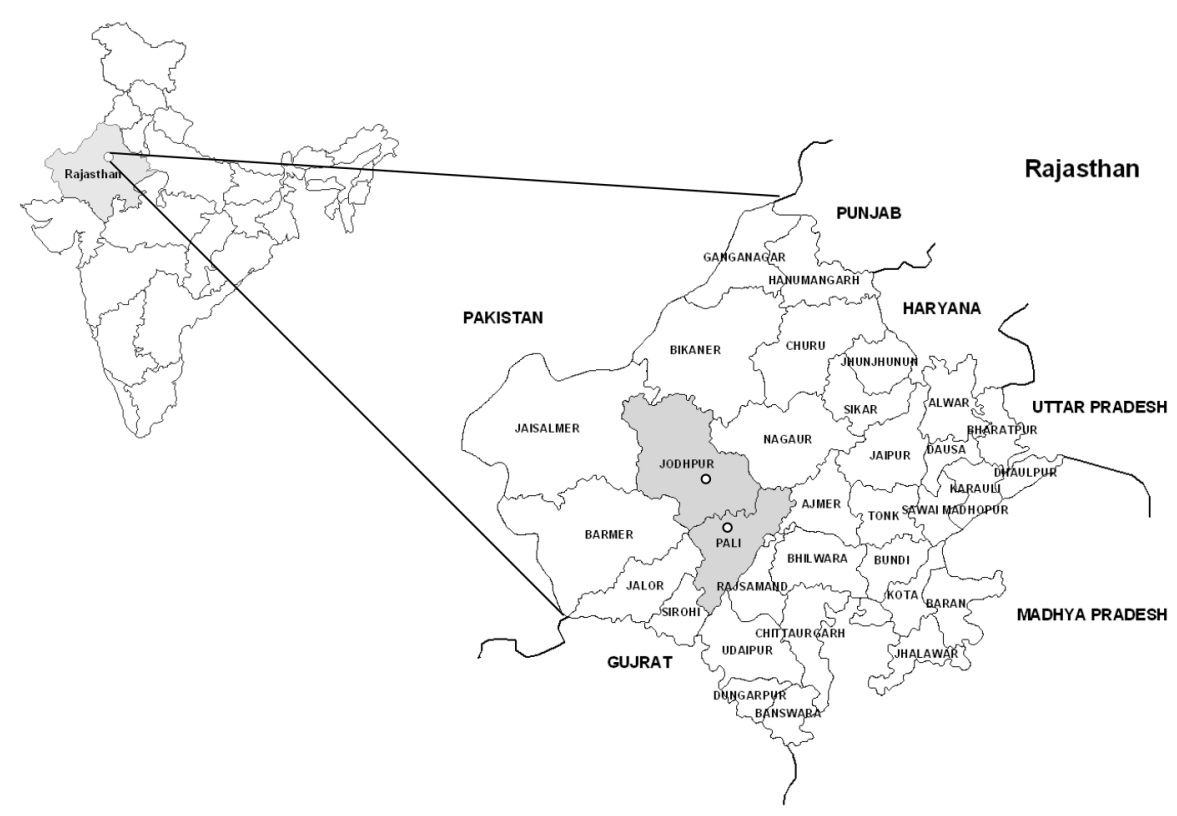

Figure Map of India and Rajasthan showing the location of textile industries in the present study.

health problems and their association, if any, with nutrition and environmental factors.

\section{Subjects and Methods}

Figure

The great Indian desert commonly called Thar, is spread over $285,680 \mathrm{~km}^{2}$, between $22^{\circ} 30^{\circ} \mathrm{N}$ and $32^{\circ} 50^{\circ} \mathrm{N}$ and from $68^{\circ} 05^{\circ} \mathrm{E}$ to $75^{\circ} 45^{\circ} \mathrm{E}$. Within India it forms a part of the country's north west arid zone in the states of Rajasthan (69\%), Gujrat (21\%) and Punjab and Haryana $(10 \%)$. The desert is borderded by the irrigated plains of the river Indus in the West, the Aravalli hill ranges in the east, the Rann of Kutch in the South and the plains of Punjab and Haryana in the north and northeast. The greater part of desert remains arid to hyper arid throughout the year. The annual precipitation is low, ranging from less than $100 \mathrm{~mm}$ in the West to about $500 \mathrm{~mm}$ in the east. It is highly erratic. About $90 \%$ of rainfall is received in the months of July and August. Delayed onset and early withdrawal of the monsoon, the main source of rain is quite common. Summer temperature is high, reaching up to $50^{\circ} \mathrm{C}$ in May and June in some places. Dust storms are quite common with wind velocities above $50 \mathrm{kph}$. During the last century, the arid region experienced 47-62 percent droughts of varying intensities. The desert dwellers have for centuries lived under harsh conditions with a bare minimum of potable water fetched from far off places and stored as a precious treasure. Milk and milk products are usually available in plenty, but not drinking water. In years of good rainfall, ponds, underground tanks and sublets of ponds turn into water reservoirs, serving human and livestock requirements ${ }^{8}$.

\section{Subjects and Data}

In the desert parts of Rajasthan about 700 textile enterprises are situated in the Pali, Jodhpur and Barmer districts, and they engage nearly 21,000 workers in various activities such as dyeing, printing and bleaching. Only the first two districts were included in this study. $\mathrm{WHO}^{9)}$ criteria for random sampling were used in estimating the sample size on the basis of $10 \%$ prevalence of malnutrition and morbidity and $20 \%$ relative precision as observed in earlier studies (Moser and Kelton ${ }^{10)}$, Waterlow, et al. ${ }^{11)}$ and Healy M.J.R ${ }^{12)}$ ). The required sample size was estimated to be 864 . For the comparative group, fifty percent of the required sample of textile workers, i.e. 430, were taken for comparison. The textile enterprises were selected using systematic sampling. The individuals were selected based on the Simple Random Sampling (SRS) technique from each textile enterprise. The comparative group were selected randomly by matching their age groups and smoking habits (interviewed in the beginning about age and smoking habits and then proceeded further), residing in 8 communities situated in the vicinity of the textile enterprises. The occupations of the comparative group were mainly service, gardeners, electricians, small shopkeepers, carpenters and tailors.

A total of 1,240 individuals were interviewed (mentioned below) out of which 845 were textile workers employed in 33 textile enterprises located in the Pali and Jodhpur districts and 395 were from the comparative group. Textile workers were working for $10 \mathrm{~h}$ only in one shift.

From each worker, information on socio-demographic, economic aspects, duration of exposure and smoking 
habits was recorded in pre-structured schedules following the interview technique. For environmental factors, housing conditions and personal hygiene were recorded. In assessing housing conditions, 10 parameters were considered for the household of each worker: type of house, ventilation and light, no. of living rooms, cleanliness, animals kept in the house, kitchen, water supply and adequacy, disposal of refuse and waste water disposal, and after scoring the assessment was made as poor, fair and good. In personal cleanliness, 10 parameters were taken: bath, hair, dress, footwear, bowel habit, nail, face, hand washing before meals, hand washing type and louse infestation, and after scoring the grading was done. Workers who had worked in the textile industry for at least one year or more were included in the present study. Each worker was examined for present illnesses, dietary intake $(24 \mathrm{~h}$ recall oral questionnaire method $^{13)}$ ) and clinical examination for nutritional deficiency signs along with height and weight following WHO standard techniques ${ }^{13)}$. Haemoglobin estimation was done by cynmethaemoglobin technique (filter paper method $)^{14)}$. Ethical approval of the study was given by the ethical committee of the Desert Medicine Research Centre, Jodhpur.

\section{Statistical Method}

Chi-square test was applied among different work categories of textile workers and the comparative group to test the strength of associations in disease conditions. The proportion test was applied as per their feasibility for application ${ }^{15)}$ to identify significant differences between disease conditions, morbidity and environmental factors in textile workers.

\section{Results}

Table 1 shows the age and gender distribution of the workers. Textile hand processing work has been categorized into four groups: caustisizing and bleaching, dyeing, printing and finishing. In the textile industry, 96.9 percent were male workers and the majority of them

Table 1. Age and gender distribution of workers and the comparative group according to type of textile work ( $\mathrm{N}=845 \&$ comparative group $=395$ )

\begin{tabular}{|c|c|c|c|c|c|c|c|c|c|c|c|c|}
\hline \multirow[t]{2}{*}{ Age Group } & \multicolumn{2}{|c|}{$\begin{array}{c}\text { Causting } \\
\text { \& Bleaching }\end{array}$} & \multicolumn{2}{|c|}{ Dyeing } & \multicolumn{2}{|c|}{ Printing } & \multicolumn{2}{|c|}{ Finishing } & \multicolumn{2}{|c|}{ Total } & \multicolumn{2}{|c|}{$\begin{array}{c}\text { Comparative } \\
\text { group }\end{array}$} \\
\hline & M & F & M & $\mathrm{F}$ & M & $\mathrm{F}$ & M & $\mathrm{F}$ & M & $\mathrm{F}$ & M & $\mathrm{F}$ \\
\hline$<18$ & 0 & 0 & 11 & 0 & 14 & 0 & 14 & 1 & 39 & 1 & 20 & 2 \\
\hline $18-30$ & 39 & 0 & 67 & 4 & 186 & 0 & 171 & 0 & 463 & 4 & 173 & 15 \\
\hline $30-40$ & 30 & 0 & 53 & 10 & 54 & 0 & 70 & 4 & 207 & 14 & 95 & 7 \\
\hline $40-50$ & 7 & 0 & 21 & 5 & 22 & 0 & 36 & 1 & 86 & 6 & 58 & 5 \\
\hline$>50$ & 1 & 0 & 8 & 1 & 2 & 0 & 13 & 0 & 24 & 1 & 19 & 1 \\
\hline Total & 77 & 0 & 160 & 20 & 278 & 0 & 304 & 6 & 819 & 26 & 365 & 30 \\
\hline
\end{tabular}

Table 2. Morbidity profile of textile workers in different types of work

\begin{tabular}{|c|c|c|c|c|c|c|c|c|c|c|c|c|}
\hline \multirow[t]{3}{*}{$\begin{array}{l}\text { Total workers } \\
\text { Comparative }\end{array}$} & \multirow{2}{*}{\multicolumn{2}{|c|}{$\begin{array}{l}\text { s: } 845 \\
\text { group: } 395\end{array}$}} & \multicolumn{4}{|c|}{$\begin{array}{l}\text { Sick: } 447(52.9 \%) \\
\text { Sick: } 183(46.3 \%)\end{array}$} & \multirow{2}{*}{\multicolumn{2}{|c|}{ Finishing }} & \multirow{2}{*}{\multicolumn{2}{|c|}{ Total }} & \multirow{2}{*}{\multicolumn{2}{|c|}{$\begin{array}{c}\text { Comparative } \\
\text { group }\end{array}$}} \\
\hline & & & \multicolumn{2}{|c|}{ Dyeing } & \multicolumn{2}{|c|}{ Printing } & & & & & & \\
\hline & No & $\%$ & No. & $\%$ & No. & $\%$ & No. & $\%$ & No. & $\%$ & No. & $\%$ \\
\hline Aches & 12 & 15.6 & 46 & $25.5^{* *}$ & 52 & $18.7 * *$ & 54 & $17.4 *$ & 164 & 19.4 & 46 & 11.6 \\
\hline Respiratory & 11 & $14.3^{*}$ & 21 & 11.7 & 44 & $15.8 * *$ & 26 & 8.4 & 102 & 12.1 & 31 & 7.8 \\
\hline Fever & 7 & 9.1 & 12 & 6.7 & 25 & $8.9^{*}$ & 21 & 6.8 & 65 & 7.7 & 19 & 4.8 \\
\hline Gastric Problem & 6 & 7.8 & 11 & 6.1 & 30 & 10.8 & 22 & 7.1 & 69 & 8.2 & 32 & 8.1 \\
\hline Skin & 3 & 3.9 & 11 & 6.1 & 7 & 2.5 & 14 & 4.5 & 35 & 4.1 & 19 & 4.8 \\
\hline General Weakness & 2 & 2.6 & 4 & 2.2 & 13 & 4.7 & 11 & 3.5 & 30 & 3.6 & 13 & 3.3 \\
\hline Eye & 2 & 2.6 & 3 & 1.7 & 2 & 0.7 & 6 & 1.9 & 13 & 1.5 & 11 & 2.8 \\
\hline Urinary Tract Infection & 1 & 1.3 & 5 & 2.8 & 3 & 1.1 & 2 & 0.6 & 11 & 1.3 & 5 & 1.3 \\
\hline Ear & - & - & 3 & 1.7 & 1 & 0.3 & - & - & 4 & 0.5 & 4 & 1.0 \\
\hline Others & 3 & 3.9 & 9 & 1.1 & 3 & 3.9 & 18 & 2.1 & 33 & 3.9 & 20 & 5.1 \\
\hline
\end{tabular}

${ }^{* *} p<0.01$ (Textile workers group v/s comparative group), ${ }^{*} p<0.05$ (Textile workers group v/s comparative group) 
Table 3. Distribution of textile workers and comparative group according to anemia

\begin{tabular}{|c|c|c|c|c|c|c|c|c|c|c|c|c|c|}
\hline \multicolumn{8}{|c|}{ Textile workers: 765} & \multicolumn{6}{|c|}{ Comparative group: 350} \\
\hline \multirow{2}{*}{$\begin{array}{l}\text { Hb Grades } \\
\mathrm{gm} / \mathrm{d} l\end{array}$} & \multirow{2}{*}{ Gender } & \multicolumn{2}{|c|}{ Caust.\& Bleach } & \multicolumn{2}{|c|}{ Dyeing } & \multicolumn{2}{|c|}{ Printing } & \multicolumn{2}{|c|}{ Finishing } & \multicolumn{4}{|c|}{ Total Comparative group } \\
\hline & & No. & $\%$ & No. & $\%$ & No. & $\%$ & No. & $\%$ & No. & $\%$ & No. & $\%$ \\
\hline Normal & M & 26 & 38.2 & 42 & 35.0 & 70 & 29.4 & 105 & 34.6 & 243 & 33.2 & 138 & 42.7 \\
\hline \multirow[t]{2}{*}{$=>13$} & $\mathrm{~F}$ & - & - & 13 & 68.4 & - & - & 3 & 50.0 & 16 & 64.0 & 12 & 44.4 \\
\hline & $\mathrm{T}$ & 26 & 38.2 & 55 & 39.6 & 70 & 29.4 & 108 & 34.6 & 259 & 34.2 & 150 & 42.8 \\
\hline Mild & M & 32 & 47.1 & 32 & 26.7 & 137 & 57.6 & 108 & 35.6 & 309 & 42.2 & 127 & 39.3 \\
\hline \multirow[t]{2}{*}{$10-<13$} & $\mathrm{~F}$ & - & - & 5 & 26.3 & - & - & 2 & 33.3 & 7 & 28.0 & 11 & 40.7 \\
\hline & $\mathrm{T}$ & 32 & 47.1 & 37 & 26.6 & 137 & $57.6 * *$ & 110 & 35.3 & 316 & 41.7 & 138 & 39.4 \\
\hline Moderate & M & 8 & 11.8 & 34 & 28.3 & 27 & 11.3 & 85 & 27.8 & 154 & 21.0 & 55 & 17.0 \\
\hline \multirow[t]{2}{*}{$7-<10$} & $\mathrm{~F}$ & - & - & 1 & 5.2 & - & - & - & - & 1 & 4.0 & 3 & 11.1 \\
\hline & $\mathrm{T}$ & 8 & 11.8 & 35 & 25.2 & 27 & 11.3 & 85 & 27.2 & 155 & 20.5 & 58 & 16.6 \\
\hline Severe & M & 2 & 2.9 & 12 & 10.0 & 4 & 1.7 & 8 & 2.6 & 26 & 3.6 & 3 & 0.9 \\
\hline \multirow[t]{2}{*}{$<7$} & $\mathrm{~F}$ & - & - & - & - & - & - & 1 & 16.7 & 1 & 4.0 & 1 & 3.7 \\
\hline & $\mathrm{T}$ & 2 & 2.9 & 12 & 8.6 & 4 & 1.7 & 9 & 2.9 & 27 & 3.6 & 4 & 1.1 \\
\hline
\end{tabular}

${ }^{* *} p<0.01$ (Textile workers group v/s comparative group), ${ }^{*} p<0.05$ (Textile workers group v/s comparative group)

Table 4. Mean and standard deviation of haemoglobin in textile workers and comparative group

\begin{tabular}{lcccccc}
\hline \multicolumn{2}{l}{ Textile Workers:765 } & \multicolumn{3}{c}{ Controls: 350} \\
\hline Hb Grades & Gender & Caust. \& Bleach & Dyeing & Printing & Finishing & Comparative group \\
\cline { 2 - 7 } gm/d $l$ & & Mean \pm SD & Mean \pm SD & Mean \pm SD & Mean \pm SD & Mean \pm SD \\
\hline Normal & M & $15.1 \pm 1.57$ & $16.1 \pm 1.92$ & $14.8 \pm 1.74$ & $15.8 \pm 2.13$ & $14.1 \pm 1.03$ \\
$>13$ & F & - & $15.9 \pm 1.79$ & - & $16.0 \pm 2.23$ & $14.8 \pm 1.21$ \\
Mild & M & $11.5 \pm 0.88$ & $11.3 \pm 0.97$ & $11.6 \pm 0.86$ & $11.5 \pm 0.83$ & $11.3 \pm 0.77$ \\
$10-<13$ & F & - & $11.5 \pm 1.14$ & - & $11.7 \pm 0.07$ & $11.5 \pm 0.76$ \\
Moderate & M & $8.4 \pm 0.89$ & $8.5 \pm 0.86$ & $9.1 \pm 0.76$ & $8.6 \pm 0.93$ & $8.8 \pm 0.80$ \\
$7-<10$ & F & - & $7.5 \pm 0.0$ & - & - & $8.9 \pm 0.93$ \\
Severe & M & $5.5 \pm 0.56$ & $5.6 \pm 0.77$ & $5.9 \pm 0.79$ & $5.4 \pm 0.81$ & $5.5 \pm 1.22$ \\
$<7$ & F & - & - & - & $6.2 \pm 0.00$ & $6.9 \pm 0.00$ \\
\hline
\end{tabular}

$(55.3 \%)$ belonged to the 18 to $30 \mathrm{yr}$ of age group. Illiteracy was 21.0 percent. Most textile workers (92.6\%) belonged to the Hindu religion. The majority of textile workers $(76.4 \%)$ had monthly incomes less than Rupees 3000. Nearly $85.0 \%$ of textile workers were living in poor or fair housing conditions. Regarding their smoking habits, 51.4 percent were found to smoke various types of tobacco, such as Beeri $(25.0 \%)$, Gutka (30.1\%), and Zarda $(37.7 \%)$. Beeri is dried tobacco leaf fragments rolled in tendu leaf (Botanical name: Diospyros melanoxylon). Gutka are flakes of tobacco mixed with betel nut pieces. Zarda is powdered tobacco.

Sickness at the time of survey was higher among the textile workers $(52.9 \%)$ than the comparative group $(46.3 \%)$. The main morbidities reported at the time of the survey among textile workers were aches (body ache, backache and headache, 19.4 percent), respiratory $(12.1 \%)$ and fever $(7.7 \%)$. These percentages were higher than the comparative group, 11.6 percent, 7.8 percent and 4.8 percent, respectively (Table 2 ). Other disease conditions such as general weakness, urinary tract infection (UTI), etc. were comparable in both the groups. Among the textile workers, gastric problems, respiratory, fever and general weakness were higher in the group engaged in printing work, followed by bleaching, finishing and dyeing, whereas, aches and skin problems were higher in the dyeing group.

Anemia was higher among textile workers $(66.0 \%)$ than in the comparative group $(57.2 \%)$. Textile workers falling in the moderate anemia category $(7-10 \mathrm{gm} / \mathrm{d} l)$ were higher $(20.5 \%)$ than that of the comparative group $(16.6 \%)$. The dyeing group workers were found to suffer 
Table 5. Prevalence of nutritional deficiency signs in textile workers and comparative group

\begin{tabular}{|c|c|c|c|c|}
\hline \multirow[t]{2}{*}{ Nutritional deficiency signs } & \multicolumn{2}{|c|}{ Textile workers } & \multicolumn{2}{|c|}{ Comparative group } \\
\hline & No & $\%$ & No & $\%$ \\
\hline \multicolumn{5}{|l|}{ Protein calorie malnutrition signs } \\
\hline Dispigmentation of hair & 10 & 1.2 & 3 & 0.7 \\
\hline Dryness of hair & 3 & 0.4 & 1 & 0.2 \\
\hline Sparseness hair & 2 & 0.2 & - & \\
\hline Total & 15 & 1.8 & 4 & 0.9 \\
\hline \multicolumn{5}{|l|}{ Vitamin A deficiency } \\
\hline Night blindness & - & - & - & - \\
\hline Bitot spot & 17 & 2.0 & - & - \\
\hline Xerosis & 1 & 0.1 & 1 & 0.1 \\
\hline Total & 18 & 2.1 & 1 & 0.2 \\
\hline \multicolumn{5}{|l|}{ Vitamin B complex deficiency } \\
\hline Angular stomatitis & 11 & 1.3 & - & - \\
\hline Cheliosis & 17 & 2.0 & 2 & 0.5 \\
\hline Glossitis & 6 & 0.7 & 4 & 1.0 \\
\hline Total & 34 & 4.0 & 6 & 1.5 \\
\hline Gums bleeding & 130 & 15.4 & 47 & 11.9 \\
\hline Swollen red papillae & 6 & 0.7 & 1 & 0.2 \\
\hline Teeth caries & 206 & 24.4 & 95 & 24.0 \\
\hline Mottled enamel & 93 & 11.0 & 20 & 5.1 \\
\hline Teeth caries \& mottled enamel & 54 & 6.4 & 29 & 7.3 \\
\hline Thyroid & 2 & 0.2 & - & - \\
\hline
\end{tabular}

Table 6. Means and standard deviation of nutrients in textile workers with RDA, ICMR

\begin{tabular}{lcccccc}
\hline Mean \pm SD & Calories $(\mathrm{Kcal} / \mathrm{d})$. & Proteins $(\mathrm{g} / \mathrm{d})$ & Fats $(\mathrm{g} / \mathrm{d})$ & Iron $(\mathrm{mg} / \mathrm{d})$ & Calcium $(\mathrm{mg} / \mathrm{d})$ & Vitamin A(mcg/d) \\
\hline Textile Workers & $2284.6 \pm 235.29$ & $75.1 \pm 7.89$ & $34.8 \pm 2.96$ & $37.9 \pm 4.66$ & $498.9 \pm 33.36$ & $1371.9 \pm 101.91$ \\
RDA*, ICMR & 2875 & 60 & 20 & 28 & 400 & 2400 \\
\hline
\end{tabular}

*Recommended dietary allowances, Indian Council of Medical Research.

most from severe anemia $(8.6 \%)$ as shown in Tables 3 and 4.

Regarding nutritional deficiency signs, protein calorie malnutrition, vitamin $\mathrm{A}, \mathrm{B}$ complex and $\mathrm{C}$ deficiencies were higher among textile workers $(1.8,2.1,4.0 \& 16.1 \%)$ than in the comparative group workers $(0.9,0.2,1.5 \&$ $12.1 \%)$. The dietary analysis revealed that the diet of textile workers was deficient in calories $(20.5 \%)$ and Vitamin A $(42.9 \%)$ in comparison to recommended dietary allowances (RDA), Indian Council of Medical Research (ICMR $)^{16)}$. This may be responsible for vitamin A deficiency and protein calorie malnutrition (PCM) (Tables 5 and 6).

Anthropometrically, body mass index was calculated in order to observe the extant of malnutrition according to WHO categories. Among textile workers, $43.8 \%$ suffered from chronic energy malnutrition, significantly higher than in the comparative group (38.2\%). Marginal and moderate thinness were higher among the workers engaged in the dyeing work followed by finishing and printing work, and were least observed in the caustisizing and bleaching work.

In textile workers, overall morbidity has also been correlated with the environmental factors, housing conditions and personal hygiene, education, income and anemia. Overall morbidity was significantly higher $(p<0.01)$ in textile workers suffering from anemia $(71.3 \%)$ compared to those without anemia (28.7\%). In good housing conditions, overall morbidity $(15.0 \%)$ was significantly $(p<0.01)$ lower than poor and fair conditions $(85.0 \%)$. Similar results were found with personal hygiene: morbidity declined with good hygiene $(4.5 \%)$ and was high in poor and fair conditions (95.5\%). Education and income also showed a negative association 
with morbidity: 5.7 percent in high education (secondary and above) and $79.6 \%$ in low education (primary level) with 90.6 percent in the lower income group (monthly income less than Rupees 3000) and 9.4 percent in the higher income group (monthly income more than Rupees 3000).

\section{Discussion}

The most frequent complaints reported by textile workers were aches and respiratory disorders. Respiratory disorders may be due to the dusty work environment. An earlier study ${ }^{4}$ conducted at the Bahir Dar Textile Mills also reported the most frequent complaints reported by the workers within a period of one month were symptoms related to the respiratory system. In others studies, also, the major health problems associated with cotton dust were respiratory problems including bissinosis, cough, bronchitis and bronchial asthma ${ }^{2,3)}$. Other disease conditions related to working in textile mills which have been reported are musculoskeletal pains, headache, easy fatigue and changes in blood pressure ${ }^{2,17)}$. These conditions were also observed in the present study: textile workers suffered from aches (body ache, backache, headache) almost twice as much as the comparative group indicating textile workers are highly exposed to physical labour which affects their musculoskeletal systems.

Dyeing group workers suffered the most from aches at a significantly higher rate $(p<0.01)$ than the comparative group. This may be due to their higher rates of severe anemia in addition to physical labour, indicating association of morbidities not only with occupation but also with anemia. The $\mathrm{WHO}^{18)}$ stressed that disease prevention through prompt attention to nutrition and to various aspects of environmental health should be priority research. In a study ${ }^{19)}$ on adults of the Raika community (OBC) of Jodhpur district, prevalence of severe anemia was observed to be high, 3.4 percent. Diseases and malnutrition are closely linked. Malnourished populations are more susceptible to most infections and severity of illness worsens the mortality rates $\left(\mathrm{WHO}^{20,21)}\right)$.

Printing and bleaching group workers were suffering from respiratory problems $(15.5 \%)$ almost twice as much as that of the comparative group $(p<0.01)$, which may be due to greater exposure to acid fumes and use of chemical dyes, as reported earlier ${ }^{6)}$. Skin complaints were observed to be higher in the dyeing group, though statistically insignificant, which may be due to not using safety gloves, aprons, etc. while working.

Disease/morbidity showed a negative association with housing conditions, personal hygiene, education and income, but was positive with anemia. Nearly $85.0 \%$ of textile workers were living in poor or fair housing conditions. Many textile workers were also residing in industry compounds thereby experiencing environmental pollution during their off-work hours, further enhancing their disease profile.

This study suggests the need for implementation of protective measures such as installation of hoods, dust filters, ventilators, general cleanliness and other safety measures such as use of gloves on hands and shoes on feet, aprons, masks, etc. so as to reduce the risks of respiratory problems. Efforts should be made to implement safety measures according to the type of work in textile industry. For example, printing and bleaching group workers were suffering more from respiratory problems, and dyeing and printing workers were suffering more from musculoskeletal pains as working conditions vary with the category of work. In addition to this, health and nutrition education and welfare programs should be organized for textile workers.

\section{References}

1) World Health Organization: Global strategy on occupational health for all-The way to health at work, 1-15 (2004)

2) RSF Shilling: Health protection and promotion at work. Br J Ind Med 46, 683-688 (1989)

3) MKB Molyneux and JBL Tombleson: An epidemiological study of respiratory symptoms in Lancashire mills, 1963-66. Br J Ind Med 27, 225-234 (1970)

4) F Mesganaw and A Yekoye: Self reported disease conditions among workers of the textile mill in Bahir Dar, Northwest Ethopia. Ethiop J Health Dev 13, 151156 (1999)

5) M Woldeyohannis, Y Bergevine, AY Mgeni and G Theriault: Respiratory problems among textile mill workers in Ethiopia. Br J Ind Med 48, 110-115 (1991)

6) JR Parikh, LJ Bhjagia, PK Majumdar, AR Shah and SK Kashyap: Prevalance of byssinosis in textile mills in Ahmedabad, India. Br J Ind Med 46, 787-790 (1989)

7) Saroj Gupta and BK Gupta: A study of byssinosis and associated respiratory disorders in cotton mill workers. Ind J Chest Dis Allied Sci 28, 183-188 (1988)

8) Central Arid Zone Research Institute: Symposium on Impact of Human Activities on Thar desert environment organized by Arid Zone Research Association of India, held at CAZRI from 15-17 Feb., Jodhpur, 2001.

9) World Health Organization. The management of nutrition in major emergencies. Geneva: WHO, 2000.

10) Moser SC, Kalton G: Survey methods in social investigations. Second Edition Heinemann educational Books Ltd. and English Book Society, 1964: 6.

11) JC Waterlow, R Buzina, W Keller, JM Lane, MZ Nichaman and JM Tanner: The presentation and use of height and weight data for comprising the nutritional status of groups of children under the age of 10 years. Bull WHO 55, 489 (1977)

12) MJR Healy: Notes on statistics of growth standards. Ann Hum Biol 1, 41 (1974)

13) DB Jelliffe. The assessment of the nutritional status of the community. Geneva: WHO, 1966. 
14) World Health Organization: Preventing and controlling Iron Deficiency Anemia Through primary health Care, A guide for Health administrators and program managers. Geneva: WHO, 1989.

15) Snedecor GW, Cochran WG. Statistical methods. Iowa: The Iowa State University Press, 1967: 593.

16) Indian Council of Medical Research. Nutrient requirements and recommended dietary allowances for Indians, New Delhi, 1990: 11-12.

17) JM Hernigton: Work related diseases and injuries. BMJ 303, 908-910 (1991)

18) World Health Organization. The management of nutrition in major emergencies. Geneva: WHO, 2000.

19) Desert Medicine Research Centre. A preliminary survey of Nutritional status of adult population of Raika community in Jodhpur district, Rajasthan. Annual report. DMRC, Jodhpur 2004: 69.

20) World Health Organization: Physical status: The use and interpretation of Anthropometry. WHO. TRS. 854, Geneva, 1995.

21) World Health Organization, Management of severe malnutrition: a manual for physicians and other senior health workers, Geneva: WHO, 1999. 